\title{
HAGIOGRAPHY AND NATIONAL CONSCIOUSNESS: THE CASE OF SANT BEUNO OF WALES
}

\author{
KAREN StÖber \\ UNIVERSITAT DE LLEIDA \\ SPAIN
}

Date of receipt: $2^{\text {nd }}$ of January, 2019

Final date of acceptance: $6^{\text {th }}$ of May, 2019

\section{Abstract}

This article looks at ways in which the political situation in medieval Wales was reflected in the writings of native authors, and in particular in the medieval Welsh hagiography. It discusses how native Welsh saints were used, on the one hand, as tools of propaganda and portrayed as defenders and protectors of their land in the face of the foreign, English adversary, and on the other, how they served to promote and justify the native Welsh church and emphasise its antiquity and its primacy vis-à-vis the advancing Anglo-Norman church. Focusing on one popular figure among the multitude of Welsh saints, the case of Saint Beuno, who is little-known outside Wales, the article then explores the ways in which this holy man's vita was constructed and used as a 'nationalist' device, tying it in with other examples of 'nationalist' Welsh literature composed during times of political crises. ${ }^{1}$

\section{KEYWORDS}

Wales, Saint Beuno, hagiography, propaganda, England.

\section{Capitalia verba}

Wallia, Sanctus Bonus, Hagiographia, propaganda, Anglia. 
Wales in the Middle Ages was a region characterized as much by its political fragmentation as by the multitude of its saints, and this paper aims to demonstrate how both of these aspects are indeed closely related. This is a topic that has long generated interest among scholars of medieval Wales, and was addressed particularly well a decade and a half ago by some of the contributors to Jane Cartwright's superb volume on Celtic Hagiography and Saints' Cults, notably Elissa Henken, Nerys Ann Jones and Morfydd Owen, J. Wyn Evans, and Jane Cartwright. ${ }^{2}$ The present article looks at just a couple of examples to further illustrate the relation between hagiography and politics in medieval Wales. It takes as its focus the vita of the popular Welsh saint Beuno, whose cult is, however, little-known outside Wales. St Beuno's Life is used here to exemplify a series of observations regarding the ways in which the written culture of the country mirrors the political events of the later Middle Ages on the one hand, and represents a reaction to the impact of the Norman Conquest on the native Welsh church on the other.

\section{The medieval kingdoms of Wales}

Throughout almost the entire medieval period, the political history of Wales was marked by the rivalry between its small kingdoms, a rivalry that was played out especially between the northern, the southern and the eastern regions of Wales in the kingdoms of Gwynedd, Deheubarth and Powys. ${ }^{3}$ The power balance among these three principal kingdoms was periodically changing and being redefined throughout the Middle Ages, alternating between the growth of one or other kingdom through conquest, and the reduction of the same, following the division of kingdoms between heirs, sometimes several of them. Thus it was in the thirteenth century, under the northern Welsh prince Llywelyn ab Iorwerth of Gwynedd (d. 1240), known as Llywelyn Fawr (the Great), who extended his territories to the south and east and at some point referred to himself as dominus Wallie, ${ }^{4}$ that medieval Wales came perhaps closest to something approaching political unity and achieved its widest territorial expansion. ${ }^{5}$

\footnotetext{
1. This paper was written within the framework of the research project Expresividad, sentimiento y emoción (s. XII-XV) (HAR 2016-75028-P), financed by the Spanish Ministry of Economy and Competitivity.

2. Cartwright, Jane, ed. Celtic Hagiography and Saints' Cults. Cardiff: University of Wales Press, 2003.

3. On the political formation of medieval Wales, see for example Davies, R.R. The Age of Conquest. Wales 1063-1415. Oxford: Oxford University Press, 1991: 24-81; Carpenter, David. The Struggle for Mastery. The Penguin History of Britain 1066-1284. Harmondsworth: Penguin, 2004: 164-167, 186-188, 300-327, 382386; Turvey, Roger. The Welsh Princes, 1063-1283. London: Longman, 2002.

4. Davies, R.R. The Age of Conquest...: 246. Llywelyn had already used the title tocius norwallie princeps ("prince of the whole of north Wales") as early as 1199: Davies, R.R. The Age of Conquest...: 239.

5. On Llywelyn ab Iorwerth, note especially Davies, R.R. The Age of Conquest... and Carr, A.D. Medieval Wales. New York: St. Martin's Press, 1995: 54-60.
} 
And it was under the rule of his grandson, Llywelyn ap Gruffudd (d.1282), who succeeded in partially reuniting the lands of his grandfather, ${ }^{6}$ which had been divided between himself and his brother Owain, that comparative calm was temporarily reestablished in the region. The Welsh Chronicle of the Princes (Brut y Tywysogyon) notes under the year 1264, "that year the Welsh lived in peace with the English, with Llywelyn ap Gruffudd prince over all Wales". ${ }^{7}$ But Llywelyn ap Gruffudd, as well as reasserting Gwynedd's position as the predominant Welsh kingdom, and in part on account of his territorial supremacy in the region, had a difficult relationship with the English crown, like many Welsh rulers before him. ${ }^{8}$ In his case, however, his repeated confrontation with Edward I of England was to have grave and lasting consequences, both for himself, and for Wales. By 1282 Edward I had mounted an unrestrained military campaign into Wales that led to the defeat and death of Llywelyn and the loss of Wales's independence. The administration of the country was taken into the hands of English royal officials. Edward's military conquest was accompanied by a large-scale building programme in the north and west of Wales that resulted in the erection of such magnificent structures as the castles of Harlech, Caernarfon, Conwy, and Beaumaris, all still visible and still impressive to this day, and standing as visual reminders of the supremacy —or, as has been argued, of the struggle of asserting its authority - of the late-thirteenth-century English crown in its newly-conquered territories. ${ }^{9}$ The impact of Edward I's conquest of Wales was to have a long-lasting effect on the land and its people, not only in practical terms on the administration and political supervision of the country, but also on the sense of the political and social identity of its people.

\section{Politics and literary production in medieval Wales}

What is notable during this time of political upheaval and external government of Wales by the English crown, combined with the uneasiness and discomfort caused by the war, is the (sometimes overt) anti-English sentiment among part of the Welsh population, expressed both in the native literature of the time and visible in the Welsh chronicles and in the formal documentation concerning the region. ${ }^{10}$ It is striking

6. Davies, R.R. The Age of Conquest...: 309. On Llywelyn ap Gruffudd, see also Carr, A.D. Medieval Wales...: 62-66.

7. Brut y Tywysogyon, or The Chronicle of the Princes. Red Book of Hergest version, ed. Thomas Jones. Cardiff: University of Wales Press, 1955: 255.

8. On the delicate relationships between Welsh princes and English kings, see for example Davies, R.R. The Age of Conquest...: 289-330.

9. Morris, John Edward. The Welsh Wars of Edward I. Oxford: Oxford University Press, 1901; Pounds, N.J.G. The Medieval Castle in England and Wales: A Social and Political History. Cambridge (UK): Cambridge University Press, 1990.

10. The most famous of the Welsh chronicles is the Bruty Tywysogyon or Chronicle of the Princes. On the formal documentation, see for example the Calendar of Ancient Petitions relating to Wales, ed. William Rees. Cardiff: University of Wales Press, 1975. For a sense of the administration of Wales by the English crown, note also 
how times of political crises tended to be reflected in the literature of Wales: we might consider the revival of Welsh folk heroes from bygone centuries, or the increased literary production in the Welsh language in the fourteenth century, to represent a direct reaction to the current political circumstances. ${ }^{11}$ Rees Davies reminds us that "in a past-dominated society, historical lore was also a political statement". ${ }^{12}$ And what stands out among this lively literary production are, on the one hand, the creation of vitae of native and local saints, as well as the translation from Latin into the Welsh language of vitae of saints, including two Welsh saints; and on the other hand, the great quantity of Welsh poetry composed during this period. Both could be decidedly political, even outright hostile in tone against the unwelcome English presence in the country. Thus the fourteenth-century bard Dafydd ap Gwilym, perhaps the bestknown of all the medieval Welsh poets, speaks in one of his poems dismissively of drisais mewn gwely drewsawr ("three Englishmen in a stinking bed"). ${ }^{13}$

In one sense, then, we need to consider the production of the Welsh vitae as a reaction, at least in part, to the country's political circumstances, and in this sense as elements of propaganda for Welsh supremacy. Simultaneously in this context we need to take into account also the role of the church and its promotion of the native saints' cults, and in order to do so we ought to look back as far as the eleventh century and the arrival of the Normans in Wales, and the great impact this event had on the Welsh church. ${ }^{14}$

\section{The Norman Conquest and the Welsh church}

The Norman Conquest in Wales was in many ways unlike that of England and the famous events of 1066 and their aftermath. Following the death of King Harold and the defeat of his army at the Battle of Hastings, England swiftly came under Norman control and government. ${ }^{15}$ In Wales, by contrast, being a politically fragmented country, the conquest of the Normans was more piecemeal, more gradual, and less complete. ${ }^{16}$ It did, however, have a considerable impact upon

the Memoranda Rolls of the Exchequer relating to Wales, a useful catalogue of which is the List of Welsh Entries in the Memoranda Rolls, 1282-1343, ed. Natalie Fryde. Cardiff: University of Wales Press, 1974.

11. A point that has been made by Glanmor Williams in his magisterial work on: Williams, Glanmor. The Welsh Church from Conquest to Reformation. Cardiff: University of Wales Press, 1976, among others.

12. Davies, R. R. The First English Empire: Power and Identities in the British Isles, 1093-1343. Oxford: Oxford University Press, 2000: p. 44.

13. Gwaith Dafydd ap Gwilym, ed. Thomas Parry. Cardiff: University of Wales Press, 1979: 328 (1.48).

14. On the Norman impact on the Welsh church note Williams, Glanmor. Yr Eglwys yng Nghymru o'r Goncwest hyd at $y$ Diwygiad Protestannaidd. Cardiff: University of Wales Press, 1968, and by the same author: Williams, Glanmor. The Welsh Church...: 1-32, and Davies, R.R. The Age of Conquest...: 172-210.

15. See for example Daniell, Christopher. From Norman Conquest to Magna Carta: England 1066-1215. London: Routledge, 2003; Chibnall, Marjorie. The Debate on the Norman Conquest. Manchester: Manchester University Press, 1999.

16. Davies, R.R. The Age of Conquest...: 82-107. 
the Welsh church and ecclesiastical organisation. ${ }^{17}$ Thus the church in Wales saw the introduction of new diocesan and parish structures along the lines of those familiar on the Continent and in England. ${ }^{18}$ New religious orders arrived in Wales and brought about profound changes to native Welsh monasticism. ${ }^{19}$ The first to arrive were Benedictine monks, mostly brought to Wales from mother houses in England and France and established alongside the new Norman castles and as such regarded as a foreign element and not always very enthusiastically welcomed by the native population. ${ }^{20}$ Other important monastic "novelties" in post-Norman Wales included, crucially, the Cistercians, and the Augustinian canons, of whom the former were more favourably received among the Welsh population, while the latter played a key part in the repopulation - and thereby continuation- of some of the ancient Welsh monasteries. ${ }^{21}$

Confronted with this new reality and new administration (both ecclesiastical and political), the Welsh clergy sought to defend and consolidate their positions within this reformed church. In many ways it was a struggle, facing, as they were, the often fundamental changes that were being imposed on the ecclesiastical life of their country. Thus the Welsh church was put under the authority of the archbishop of Canterbury, in England, as well as that of the pope in Rome, though the created memory of a native Welsh archbishopric at St Davids, superior in importance to all other archbishoprics on the island, persisted in the imagination of the native clergy. ${ }^{22}$ The important offices within the church hierarchy were increasingly granted to Anglo-Norman clerics, and even within the first century of Norman presence in Wales there was a high incidence of men of Anglo-Norman origin among the bishops of the Welsh dioceses. ${ }^{23}$

\section{The promotion of Welsh saints' cults}

It was in this context of alienation within Wales and the Welsh church that the multiple cults of native Welsh saints began to be reinstated and promoted in the

17. Burton, Janet; Stöber, Karen. Abbeys and Priories of Medieval Wales. Cardiff: University of Wales Press, 2015: 7-13; Williams, Glanmor. The Welsh Church...: 1-32, and Davies, R.R. The Age of Conquest...: $172-210$. 18. Williams, Glanmor. The Welsh Church...: 14-17.

19. Williams, Glanmor. The Welsh Church...: 14-22; Burton, Janet; Stöber, Karen. Abbeys and Priories...: 9-15.

20. On the Benedictine foundations in Wales and their reception by the native population, see Burton, Janet. "Transition and Transformation: the Benedictine Houses", Monastic Wales: New Approaches, Janet Burton, Karen Stöber, eds. Cardiff: University of Wales Press, 2013: 21-37. Note also Burton, Janet; Stöber, Karen. Abbeys and Priories...: 7-10.

21. Stöber, Karen; Austin, David. "Culdees to canons: the Augustinian houses of north Wales", Monastic Wales: New Approaches, Janet Burton, Karen Stöber, eds. Cardiff: University of Wales Press, 2013: 39-54.

22. Note for example Davies, R.R. The First English Empire...: 45.

23. Cf. Williams, Glanmor. The Welsh Church...: 23-24. 
literature; first and foremost among them the cult of St David, ${ }^{24}$ and just over two centuries later, the cult of St Beuno. ${ }^{25}$ The aim of the promotion of these saintly Welsh figures and their often far-reaching cults was surely to lend weight, seniority and added credibility to a Welsh church —and a Welsh "nation" - under threat. ${ }^{26}$ And indeed, this was not an isolated occurrence: from this time onwards, especially during times of crisis, as was to be the case again in the fourteenth century, we find an increased "use" of native saints acting not only as defenders and protectors of their land, but also justifying and promoting the importance of the Welsh church, its respectability, its antiquity, and its primacy. And in fact there was no shortage of saints in medieval Wales: the late-twelfth-century historian and cleric Giraldus Cambrensis famously said about the northern Welsh island of Bardsey that "the bodies of a vast number of holy men are buried there, or so they say", ${ }^{27}$ and another source suggests that the island housed the graves of as many as 20,000 saints. ${ }^{28}$ It is not without good reason that the early medieval period in Wales is known as the "Age of the Saints". The great quantity and prominence of saints in Wales is also evident in the etymology of the country. The place-name element "Llan-", when followed by a saint's name, indicates a site which has an association with a religious cult; and these abound across Wales. ${ }^{29}$ The medieval poets, too, make frequent reference to saints, both universal saints such as the Virgin or St Catherine, and native Welsh saints, and they often apply the qualities of chosen saints to the people they are addressing in their praise-poetry. Thus a Welsh Cistercian abbot (of Strata Florida Abbey in mid-Wales) could be called the "St David of the abbots" by the fifteenth-century poet Guto'r Glyn. ${ }^{30}$ Be they military heroes or abbots of the great Welsh monasteries, the men who were considered by the Welsh poets to be the defenders of the country, its ways and its culture, were seen by them as worthy to be compared to the saints who were understood to represent both strength and wisdom.

24. For a text of the late-eleventh-century vita of St David, see: Rhigyfarch: Buched Dewi, ed. D. Simon Evans. Cardiff: University of Wales Press, 1959.

25. For the Welsh text of St Beuno's fourteenth-century vita see Wade-Evans, A.W., ed. Vitae Sanctorum Britanniae et Genealogiae. Cardiff: University of Wales Press, 1944: 16-22. On St Beuno see also BaringGould, S.; Fisher, John, eds. The Lives of the British Saints; the Saints of Wales, Cornwall and Irish Saints, ed. 4 vols. London: the Honourable Society of Cymmrodorion, 1907-1913: I, 208-221 (reprinted by Kessinger Publishing, 2005).

26. Cf. Henken, Elissa. "Welsh hagiography and the nationalist impulse", Celtic Hagiography and Saints' Cults, Jane Cartwright, ed. Cardiff: University of Wales Press, 2003: 29-30.

27. Gerald of Wales: The Journey through Wales / The Description of Wales, ed. Lewis Thorpe. Harmondworth: Penguin, 1978: 184.

28. On Bardsey see Burton, Janet; Stöber, Karen. Abbeys and Priories...: 43-45.

29. Note for instance: Llanbadarn (near Aberystwyth), a place associated with St Padarn; Llandeulo, associated with St Teulo; or Llanfair, a place associated with the Virgin Mary (Mair in Welsh).

30. Gwaith Guto'r Glyn, ed. John Llywelyn Williams, Ifor Williams. Cardiff: University of Wales Press, 1961: 29 (line 4: Dewi'r abadau = "[St] David of abbots"); (note also line 26: Dewi's glod = "[St] David of praise [poetry]"). 
In the Welsh literary tradition the saints appear not infrequently as hero figures defending their country and its people, and as such played the important role of the champions of a mythical epoch of splendour and glory, a golden age of a grand and heroic Wales. In the words of Elissa Henken,

the Welsh saints, those fifth- and sixth-century men and women [...] were generally local heroes whose cults did not extend far beyond their own immediate territories. [...] But some expanded their influence from local to regional and even national levels, playing a role in the politics of both Church and State. ${ }^{31}$

\section{The vita of Saint Beuno}

It is within this context that I will now turn to my example, the case of an important saint, much loved by the people of Wales: the seventh-century saint Beuno. Beuno is perhaps the best-known saint in north Wales, where he spent the later part of his life, while south Wales is the realm of St David, ${ }^{32}$ who is moreover distinguished by being regarded as the patron saint of all Wales. ${ }^{33}$ We might say that Beuno is the "second saint" of Wales, after David. His short Life (buchedd), in Middle Welsh, survives in various copies of one manuscript known as Llyfr Ancr Llanddewibrefi ("The Book of the Anchorite of Llanddewibrefi") from the year 1346. ${ }^{34}$ Surviving copies of Beuno's buchedd include, apart from the one preserved in the fourteenth-century Llyfr Ancr, a further version from the fifteenth century, plus several later ones. ${ }^{35}$

The text narrates the story of the saint from the marvellous events surrounding his birth until his death in the mid-seventh century. There is reason to believe that Beuno was in fact a historical character, as were several of the figures that are mentioned in his vita, and other sources corroborate some details from his Life. ${ }^{36}$ According to the vita, his elderly parents, who lived in Powys, in the mid-east of

31. Henken, Elissa. “Welsh hagiography...": 26-27.

32. For his vita see Rhigyfarch: Buched Dewi....

33. On St David see for example Evans, J. Wyn. "St David and St Davids: some observations on the cult, site and buildings", Celtic Hagiography and Saints'Cults, Jane Cartwright, ed. Cardiff: University of Wales Press, 2003: 10-25; Stöber, Karen. "An ecclesiastical identity in the making: the medieval cathedral and bishopric of St Davids (Wales)", Identity in the Middle Ages, Flocel Sabaté, ed. Kalamazoo: Pagès editors, ARC-Humanities Press, 2018: forthcoming.

34. On the Llyfr Ancr Llanddewibrefi (Book of the Anchorite of Llanddewibrefi), see: Williams, Glanmor. The Welsh Church...: 84-85.

35. Cf. Williams, Glanmor. The Welsh Church...: 104.

36. Thus for example Beuno is said to have met Cadfan, king of Gwynedd and his son Cadwallon, both historical figures ("Hystoria o Uuched Beuno". Vitae Sanctorum Britanniae et Genealogiae, ed. A.W. WadeEvans. Cardiff: University of Wales Press, 1944: 19 (§§13-15)). Similarly, Beuno's niece, Gwenfrewi or Winifred, is considered to have a historical basis. 
Wales, had given up all hope or expectation of having children when an angel appeared to his father, announcing Beuno's birth (advising his father, in fact, to have intercourse with his wife that same night, which he duly did, upon which his wife promptly fell pregnant). ${ }^{37}$ Though his parents do not otherwise feature particularly prominently in his vita, Beuno did of course have a most impressive genealogy, an important feature in Celtic literature and much in line with other Welsh saints, notably St David, and which confirmed his royal lineage as well as emphasizing his divine ancestry. ${ }^{38}$ According to the vita Beuno was educated by St Tangusius in Caerwent, a town of Roman foundation in south Wales and at that time, in the seventh century, an important ecclesiastical and educational centre. ${ }^{39}$ Later he was ordained and given some lands, a site known as Llanfeuno in Gwent (south Wales), where he founded a church or monastery, and where he was said, in his vita, to be surrounded by "disciples and monks". ${ }^{40}$ In the words of Elissa Henken,

these stories [of saints founding churches] are not just aetiologies, telling how a certain church ended up in a particular spot. Because of the divine nature of the grant they also become important political statements in the assertion of a church's rights. And politics", she continues, "was very important in the composition of the saints' Lives". ${ }^{41}$

Beuno's vita exemplifies the importance of politics, or what we may call "national consciousness", in a saint's Life, although the term "national", laden as it is with meaning, needs to be treated with considerable caution, here as elsewhere. ${ }^{42}$ By examining Beuno's Life we will see how "national" was understood by its author, and how a hagiographical text might be used as a political tool in later medieval Wales. It is here the common enemy that unites an otherwise mostly ununited people, emphasising the shared threat to a non-homogenous identity forged on the basis of a shared language, laws, and the shared prospect of the imminent loss of their territory and autonomy.

Beuno's vita tells us that while the holy man was at Llanfeuno, news reached him that his father was gravely ill, and he travelled north to Powys to see him and hear

\footnotetext{
37. "Hystoria o Uuched Beuno" ...: 16 (§2).
}

38. His genealogy reads as follows: "Beuno son of Bugi, son of Gwynlliw, son of Tegit, son of Kadell Drynlluc, son of Categyrnn, son of Gortheyrnn, son of Rittegyrn, son of Deheuwynt, son of Eudegan, son of Eudegern, son of Elud, son of Eudos, son of Eudoleu, son of Auallach, son of Amalech, son of Belim, son of Anna. The mother of this Anna was a cousin of the Virgin, mother of Christ." "Hystoria o Uuched Beuno"...: 22.

39. "Hystoria o Uuched Beuno"...: 16 (§3).

40. "Hystoria o Uuched Beuno"...: 16 (§4).

41. Henken, Elissa. “Welsh hagiography...": 29.

42. Note also Carr, A. D. "Inside the Tent Looking Out: The Medieval Welsh World View", From Medieval to Modern Wales: Historical Essays in Honour of Kenneth O. Morgan and Ralph A. Griffiths, R.R. Davies, G.H. Jenkins, eds. Cardiff: University of Wales Press, 2004: pp. 30-44; and Davies, R.R. “The Identity of 'Wales' in the Thirteenth Century", From Medieval to Modern Wales: Historical Essays in Honour of Kenneth O. Morgan and Ralph A. Griffiths, R.R. Davies, G.H. Jenkins, eds. Cardiff: University of Wales Press, 2004: 45-63. 
his confession. ${ }^{43}$ It is just after his father's death, that we hear the first miraculous story associated with Beuno. Having buried him, Beuno

...ac a blannawd vessen yn ystlys bed $y$ dat, a honno a dyfawd yno yn derwen diruawr $y$ huchet ae frasset. Ac ar vric y prenn hwnnw ef a wrthyfawd keing hyt y llawr, ac or llawr dracheuen yn ogyuuch a bric y prenn, a thrigyaw elin yr geing ar y llawr. Ac velle y mae yn w[a]stat. Ac od a Seis yrwng yr elin honno a bon y prenn, yn diannot y byd marw. Ac os Kymro a a yno, ni henuyd gwaeth. ${ }^{44}$

An Englishmen-killing tree, in other words, a blatantly hostile episode, is the first miraculous happening associated with Beuno in his vita, apart from the miraculous events surrounding his birth.

Beuno next went to see the king of Powys, who proceeded to give him some lands on which to settle, and even now there survives a rock known as Maen Beuno ("Beuno's Rock") which marks the spot on which, according to popular legend, the holy man used to stand and preach to the people. It was while he was in this place with his disciples that the next remarkable episode of his Life occurred: One day Beuno was walking by the banks of the river Severn, in what was to be the southern frontier region between Wales and England, when he heard, from across the other side of the river, the voice of a huntsman calling his dogs. That this huntsman was an Englishman is made known by the words he calls out to his dogs: kergia kergia ("charge, charge"). ${ }^{45}$ The vita refers to him as a "foreigner", gwr angkyuyeith, literally, a "man with a different language", as well as calling him a Seis, i.e. an Englishman. ${ }^{46}$ Upon hearing these calls, Beuno hurried back to where his disciples were resting and told them to gather their things. "Let us leave this place", he urged them, for "the nation of the foreigner ["the man with the different language"] who I saw on the other side of the river with his dogs will invade this country and it will be theirs and they will treat it as their possession" ${ }^{47}$ Upon which they abandoned the place and moved on. The occurrence described here is hardly a miracle; what is extraordinary about this episode, however, is Beuno's ability, granted to him by the author of his vita centuries after the events it describes, to foresee the events of the future and to recognise the danger represented by an ordinary huntsman via the language spoken by the latter. This is, of course, a most convenient episode of nationalist hue for the later medieval authors of the vita to exploit. It is interesting

43. Baring-Gould, S.; Fisher, John, eds. The Lives of the British Saints...: I, 210.

44. "planted an acorn by the side of his father's grave, and that grew into an oak that was enormous in height and thickness. And from the top of the tree a branch grew back down towards the ground, and from the ground back up as high as the tree, and the bend of the branch stayed on the ground [thereby forming an arch], and thus is remains still. And if an Englishman should pass between that bent branch and the tree trunk, he will die immediately. And if a Welshman should go there, he will not suffer". "Hystoria o Uuched Beuno"...: 17 (§6).

45. "Hystoria o Uuched Beuno"...: 17 (§8).

46. "Hystoria o Uuched Beuno"...: 17 (§8).

47. "Hystoria o Uuched Beuno"...: 17 (§8). 
to note, then, that here we have a fourteenth-century author in post-EdwardianConquest Wales, recounting a seventh-century episode signifying the Anglo-Saxon threat facing Wales at that time as he imagines it against the backdrop of his own current experience. ${ }^{48}$ And the figure of the native saint recognizes the impending danger but is unable to prevent it. Beuno and other Welsh saints of the period carried upon them a certain obligation for the well-being of their country. As Elissa Henken puts it: "Like other rulers they [the saints] bear responsibility for the total welfare of the land and people, for ensuring fertility, justice, peace and security" ${ }^{49}$ But like other rulers, the saints cannot always comply.

The remainder of Beuno's Life recounts the wanderings of the holy man through Wales, as well as relating the odd miracle associated with Beuno: thus he is credited with a number of resuscitations, which include that of a princess, that of an Irishman, and that of his own niece, St Winifred or Gwenfrewi. ${ }^{50}$ The Life further tells of Beuno's encounters with a range of political figures across Wales. Thus he is said to have had a good relationship with King Cadfan of Gwynedd (north Wales), who is in fact a historical figure who died c. 616, but not quite such a good relationship with Cadfan's son, Cadwallon. This latter, having received gifts from Beuno, so his vita tells us, gave the holy man in return certain lands, which, as it turned out, did not belong to him. When this was revealed, he was duly cursed by Beuno. ${ }^{51}$ By way of compensation, Cadwallon's cousin Gwyddaint offered Beuno his own township of Kellynnawc (Clynnog), which lies on the north coast of the Llŷn Peninsula in north Wales, which Beuno accepted and which he made his home. ${ }^{52}$ He lived in Clynnog until his death and is said to have founded a monastery at the site, which does not survive. What does survive, though, is the parish church of Clynnog, a surprisingly large and magnificent building for such a small town, hinting perhaps at its importance through its association with St Beuno. The surviving fabric of the church dates mostly from the fifteenth to sixteenth centuries, though its foundations, as well as a number of inscribed stones, prove that this has been a site of religious significance since at least the eighth century. Ffynnon Feuno, a holy well associated with St Beuno, said to cure epileptic children and "impotent folk", is near the church. ${ }^{53}$

48. Thus we find the great crises facing medieval Wales - the Saxon threat, the Norman invasion some centuries later, and the Edwardian Conquest at the end of the thirteenth century - being reflected in similar ways in the medieval Welsh literature.

49. Henken, Elissa. "Welsh hagiography"...: 27.

50. For the resurrection of the princess: "Hystoria o Uuched Beuno"...: 20 (§19); for the Irishman: "Hystoria o Uuched Beuno"...:17 (§10); For St Winifred: "Hystoria o Uuched Beuno"...: 18-19 (§13). On St Winifred see also "S. Gwenfrewi", Baring-Gould, S.; Fisher, John, eds. The Lives of the British Saints; the Saints of Wales, Cornwall and Irish Saints...: III, 185-196. Holywell in north Wales, the waters of which are believed to have healing powers and which is still a popular pilgrimage destination, is associated with St Winifred, allegedly marking the site where her head fell after she was beheaded (before being resuscitated by her uncle Beuno).

51. “Hystoria o Uuched Beuno"...: 19 (§15).

52. "Hystoria o Uuched Beuno"...: 19-20 (§16).

53. Cf. Baring-Gould, S.; Fisher, John, eds. The Lives of the British Saints...: I, 216. 
When death finally approached Beuno, his vita tells us that he had a vision of Heaven, which opened and let him see the Trinity and a multitude of saints. ${ }^{54}$ His feast day is 21 April and his grave at Clynnog along with the holy well that bears his name soon became associated with miracles and developed into a pilgrimage destination..$^{55}$

\section{Beuno's Life and 'national consciousness'}

The Life of St Beuno is a fairly short, but highly charged text. Regarded in the context of other medieval Welsh literary expressions, in particular the poetry of the period, it becomes a reflection of what we may call the "national" consciousness of its author, in the sense that he treats Wales and its people here as an entity which, in fact, the different regions and people of Wales never were, although they shared a common language and a common law. And the author of Beuno's vita demonstrates his partiality towards Wales and his concern for a country which was for him not simply a nation, but a nation threatened by another, whose administration was in the hands not of its native rulers, but of the English crown. In her excellent article on the "nationalist impulse" in Welsh hagiographic writing, Elissa Henken maintains that the fact that there was a demand for texts of this type in the Welsh language in the fourteenth century indicates what the preoccupations were in Wales at that time. ${ }^{56}$ Rees Davies points out that, similarly, the medieval Welsh prose tales reflect a certain nostalgia for a heroic past that never was. In his words, the 'memories, continuous if contrived memories, of a glorious past weighed heavily and inspiringly on the Welsh mind; they were the ideological framework for its political ambition'.$^{57}$ Referring to the Welsh hagiography, Elissa Henken argues that "these Welsh texts were written at a time of deep despair and

\footnotetext{
54. Ac val yr oed hoedyl Beuno yn daruot ae dyd yn dyuot, y seithued dyd gwedy y Pasc, ef a welei y nef yn agoret ac engylyonn yn gogwstwng ac yn dyrchauel y vynyd dracheuen. Ac yna y dywat Beuno, 'Mi a welaf (heb) y Trindawt, y Tad ar Mab ar Yspryt Glan, a Pheder, a Phawl, a D[a]uid wirion, a Deyinoel, ar seint, ar prophwydi, ar ebestyl, ar merthyri yn ymdangos ym. A mi welaf ymplith hynny seith angel yn seuyll ger bronn kadeir y goruchel Dat, a holl dadeu nef, ar kannyadaeth yn dywedut, "Gwynuydedic yw yr hwnn, a etholeisti ac a gymereist ac a bresswyla ygyt yn dragywydawl. ("And as the lifetime of Beuno was ending, and his last day drew near, on the seventh day after Easter, he saw heaven open, and the angels descending and ascending again. And Beuno said, "I see the Trinity, the Father, the Son and the Holy Spirit, and Peter and Paul, and David the innocent, and Daniel, and the saints, and the prophets, and the Apostles and the martyrs appear to me. And I see among them seven angels standing before the throne of the highest Father, and all the fathers of heaven singing and saying, "Blessed is he whom thou hast chosen and taken, and who does for ever dwell with Thee"). "Hystoria o Uuched Beuno"...: 21 (\$22).

55. Jones, G. Hartwell. Celtic Britain and the Pilgrim Movement. London: Honourable Society of Cymmrodorion, 1912: 34-35.

56. Though it is important to note that of only two Lives of native Welsh saints - those of David and Beuno - do we have versions in the Welsh language. There may have been others, but they do not survive, or have not yet been discovered.
}

57. Davies, R.R. The First English Empire...: 45. 
suffering for the Welsh, after the fall of Llywelyn II [ap Gruffudd] and the loss of independence and before even the temporary hope offered by the redeemerheroes Owain Lawgoch and Owain Glyn Dw $\mathrm{r}^{\prime \prime},{ }^{58}$ the reference being to a figure known as mab darogan, the "son of prophesy" of ancient tradition, who is alluded to in the Armes Prydein, a prophetic text that appears in the Llyfr Taliesin ("the Book of Taliesin"), which survives in a late-thirteenth-century manuscript (of c. 1275), but is of pre-1066 composition. ${ }^{59}$ This ancient Welsh text, eagerly seized upon by fourteenth- and fifteenth-century poets, foresees the appearance of the mab darogan, a redeemer figure who will make Wales great again. ${ }^{60}$ In a similar manner, the Welsh hagiographic texts of the eleventh to fourteenth centuries see in the respective saints whose vitae they recount a kind of divine political activist. They reflect, on the one hand, the political impulse of their authors and by extension of Welsh society more widely, and on the other, the impulse given by the changed situation in which the Welsh church found itself. As Glanmor Williams points out, the Life of St David, for example,

was written [in the late eleventh century] as part of a patriotic protest against Norman encroachment into the Welsh church; and one wonders whether the popularity of the Welsh version in the fourteenth century may not be connected with a sense of outrage at the growing tendency to exclude Welsh clerics from the higher echelons of the clergy during that period. ${ }^{61}$

In fact, the historical situation of the saints often reflects the actual political situation at the time of the composition of their vitae: territorial incursion and the loss of territory to foreign invaders. And in this context the Welsh saints -as indeed do saints in other traditions, too- frequently enough appear as saviours and defenders of the land, both of their immediate territory and of their country. This is true also in terms of their providing for its people, safeguarding the fertility of the land, and even engaging in military action to protect their country. ${ }^{62}$ The Welsh tradition abounds with such protector-saints: thus for example St Llawddog was associated with the fertility of the land, with bringing prosperity to "his parish, his men, his children, every harrow and yoke, all the ploughs, every furrow, every hill and ridge and all the grain". ${ }^{63}$ St Illtud miraculously moved three stores of

58. Henken, Elissa. "Welsh hagiography...": 37.

59. For a text of Armes Prydein see for example Armes Prydein. The Prophesy of Britain from the Book of Taliesin, ed. Sir Ifor Williams. Dublin: The Dublin Institute for Advanced Studies, 1972.

60. On the Welsh prophetic tradition see also: Evans, R. Wallis. "Prophetic Poetry", A Guide to Welsh Literature, 1282-c.1550, A.O.H. Jarman, Gwilym Rees Hughes, ed. Cardiff: University of Wales Press, 1997: 256-274, and Williams, Glanmor. The Welsh Church...: 215-16. And note Davies, R.R. The First English Empire...: 46.

61. Williams, Glanmor. The Welsh Church...: 104.

62. This has been discussed by Henken, Elissa. "Welsh hagiography...": 27.

63. Jones, E.D. “Lewis Glyn Cothi”, A Guide to Welsh Literature, 1282-c.1550, A.O.H. Jarman, Gwilym Rees Hughes, ed. Cardiff: University of Wales Press, 1997: 231. 
grain in order to help his people; ${ }^{64}$ St Gwynllyw single-handedly defeated an entire Anglo-Norman army that was invading Wales; ${ }^{65}$ St Cadfan was regarded as the protector of those who defended the land against invaders; ${ }^{66}$ and St Tysilio was described by the twelfth-century poet Cynddelw Brydydd Mawr as post Powys... pobyl argledyr ("pillar of Powys... protector of the people"). ${ }^{67}$ Throughout the medieval period, at times of crisis, and in particular political crisis, the Welsh saints, as the traditional protectors of land and population, were invoked by the poets, representing the voice of the people. The fifteenth-century poet Lewys Glyn Cothi made this passionate appeal at the end of one of his poems: "May these saints, each three and seven, rule Wales again! May the hope of Wales now rest in the saints of this island". ${ }^{68}$ The more formal documentation from the period, such as the petitions to the English crown, complements the hagiography and reflects the anxiety and discomfort of the Welsh people during the times of Anglo-Norman or English occupation of their country, which, it ought to be remembered, was not a politically united country, but which in the sentiment of the medieval authors becomes a "nation". In all of the above cases the saint is a figure who evokes the oldest traditions of a heroic and glorious Wales (note Rees Davies's 'past-dominated society' $)^{69}$ in a difficult, miserable and unpromising present. Moreover, these texts offer the sensation of belonging, of a shared identity. And, as Elissa Henken points out, "without that sense of identity there is no nation". ${ }^{70}$ The northern Welsh saint Beuno, as his buchedd portrays him, is just one actor on a large stage, but he represents, I think, a most illustrative case to help us appreciate the mindset of the medieval author of his vita, echoing the distress of a society under pressure during times of political upheaval.

\section{To conclude}

And the story does not end here. During the nineteenth century, following a revival in interest in all things Welsh and motivated by a new impulse or nationalist fervour in Wales, there emerged a notion of "Welsh identity" with a strong basis in the medieval past, and in this context efforts were made to promote the cults of certain native Welsh saints, notably that of St David as the country's patron saint, including the celebration of his feast day on 1 March. So even in this "age of reason" the saints still played a part in defining a "Welsh identity". We

64. Baring-Gould, S.; Fisher, John, eds. The Lives of the British Saints...: III, 303-317.

65. Baring-Gould, S.; Fisher, John, eds. The Lives of the British Saints...: III, 234-241.

66. Baring-Gould, S.; Fisher, John, eds. The Lives of the British Saints...: II, 1-9.

67. Henken, Elissa. "Welsh hagiography...": 28.

68. Cothi, Lewys Glyn. Gwaith Lewys Glyn Cothi, ed. Dafydd R. Johnston. Cardiff: University of Wales Press, 1995: 26 (lines 67-70). On Lewys Glyn Cothi, note also Jones, E.D. "Lewis Glyn Cothi"...: 222-239. 69. Davies, R.R. The First English Empire...: 44.

70. Henken, Elissa."Welsh hagiography...": 41. 
may not have the same relation to the saints as did our medieval ancestors, but the continuation of celebrations of their feast days, and the multitude of church dedications in their honour, as well as the numerous places that bear their names and preserve their memory, ensure that they are a continuing presence across Wales to this day. 